
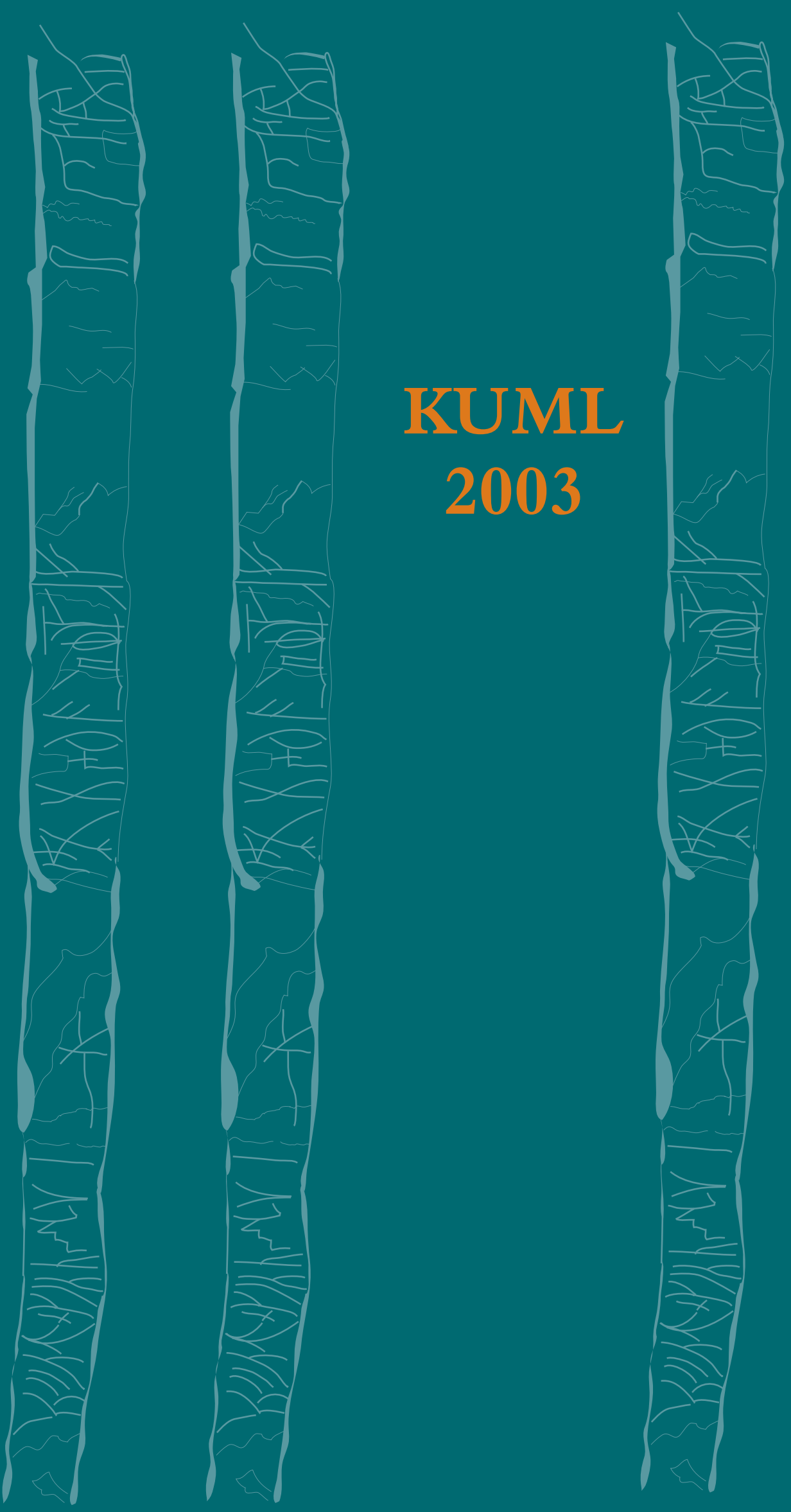


\section{KUML 2003}

Årbog for Jysk Arkæologisk Selskab

With summaries in English

I kommission hos Aarhus Universitetsforlag 


\title{
Centralpladser i romersk jernalder
}

\author{
Af ASTRID SKOU HANSEN
}

I de sidste 10-15 år er der i det sydskandinaviske område fundet flere lokaliteter fra yngre romersk jernalder, der adskiller sig fra de sædvanlige bopladser fra denne tid ved at indeholde fund, der vidner om større rigdom og forbindelser til pladser længere væk. Disse centralpladser har åbnet op for en helt anden opfattelse af jernaldersamfundet end den, der tidligere var fremherskende. Det er nu alment accepteret, at de bebyggelser, der i romersk jernalder har karakter af centralpladser, er forløbere for dem, som i vikingetiden danner basis for den samfundsstruktur, der medfører oprettelsen af kongedømmet og dermed staten Danmark.

I betragtning heraf skulle man tro, at der var et rigt og fuldt udviklet begrebsapparat til at beskrive, hvilke mekanismer det er, der gør sig gældende ved en sådan samfundsudvikling. Dette er imidlertid ikke tilfældet. Når man diskuterer centralpladser og centralpladshierarkisering, er der stort set lige så mange forskellige begreber, som der er forfattere. Formålet med denne artikel er således at forsøge at gøre rede for fordele og ulemper ved nogle af de begreber, der anvendes på området og samtidig give et overblik over, hvilke mekanismer det er, der opstår på dette tidspunkt og som får betydning for den senere statsdannelsesproces.

En af de problemstillinger, jeg finder mest interessant i denne sammenhæng, er, hvorvidt centralpladserne er centrale i forhold til de fleste eller alle aspekter af samfundets opbygning (handel, kult/religion, administration, militær osv.), eller om de kun er centrale i en eller et par henseender. Men før der kan findes et svar på dette, må begrebet centralplads defineres. Som nævnt er der i den forbindelse et hav af både eksplicitte og implicitte definitioner. Helt basalt er en centralplads en plads, der udviser tegn på at have haft en funktion, der har berørt flere mennesker end dem, som har boet på den pågældende plads. Der findes selvfølgelig mange slags centralpladser, nogle har måske kun en betydning for det nærmeste område, mens andre har haft en dominerende rolle i et stort område. Denne artikel beskæftiger sig mest med de centralpladser, der har haft betydning for en relativt stor gruppe mennesker, fordelt over ret store områder. Årsagen til dette er, at disse pladser er nemmere at erkende som centrale, og at forskerne oftest har anvendt disse pladser som eksempler. Det er dem, som 
indeholder det største og mest alsidige materiale, blandt andet bestående af import fra Romerriget. Som eksempel er der i det følgende valgt tre velkendte centralpladser, nemlig Gudme-Lundeborg komplekset, Sorte Muld og Uppåkra. Jeg har valgt netop disse tre lokaliteter, fordi de tilsammen dækker en forholdsvis stor del af det sydskandinaviske område, fordi de er brugt som eksempler på centerdannelse af forskellige forfattere, og fordi de alle har en kontinuitet fra romersk jernalder, som er det tidsrum, jeg ønsker at behandle, og til germansk jernalder, som er det tidsrum, som teorierne tager udgangspunkt i.

Men før der kan foretages en egentlig analyse af, hvad årsagen til centerdannelsen er, og hvordan den manifesterer sig, er det på sin plads kort at beskrive det samfund, der ligger til grund for centralpladserne.

\section{Centerdannelse og samfundsstruktur}

I yngre romersk jernalder forbedres de generelle levevilkår sandsynligvis. Dette bekræftes af skeletmaterialet fra tidens grave, hvor der bl.a. kan registreres en højere gennemsnitshøjde, hvilket er et resultat af bedre ernæring, ikke mindst i barndommen. Man kan også se en social differentiering af samfundet ud fra skeletterne, idet der er sammenhæng imellem højde, sundhed, tandslid og social status/position. ${ }^{1}$

Som følge af en omstrukturering i landbruget i løbet af ældre jernalder er der en tendens til, at driftsenhederne i yngre romersk jernalder er større end i de forudgående perioder. Indmark-/udmark-systemet tages i brug, og man lægger større vægt på kvæghold. Dette medfører et øget overskud, som sikkert har haft en afgørende betydning for tidens centerdannelse og samfundsudvikling. Overskudsproduktionen har sandsynligvis ikke indgået direkte i vareudveksling over større afstande, idet fødevarer og andre landbrugsprodukter generelt ikke er velegnede til længerevarende transport, men den har betydet, at det var muligt for den lokale elite at opretholde et center. Centrene i yngre romersk jernalder har antageligt ikke kunnet fungere uden denne overskudsproduktion, der blandt andet kan have været investeret i en hird. ${ }^{2}$ Ifølge Lotte Hedeager etableres der i dette tidsrum en centralmagt, som råder over en hird, og som har vasaller, ligesom der kæmpes om politisk kontrol over landområder og vigtige resurser. ${ }^{3}$ Den førnævnte omstrukturering i landbruget er ifølge Hedeager et resultat af, at den nyetablerede centralmagt indførte et nyt rets- og beskatningssystem. Dette nye system byggede på individuelle driftsenheder som juridisk grundlag. Især den nye centralmagt, men også de mest velhavende bønder, havde en interesse i denne omlægning, som betød, at de mindre gårde og jordløse huse blev lagt ind under større gårde. Dette gav mulighed for en mere effektiv drift, som igen betød et større overskud, 
men også en større klasse af jordløse, der indgik som arbejdskraft på de større gårde. Denne forklaring på ændringerne i landbruget forudsætter, at der allerede i ældre romersk jernalder var en central magtfaktor til stede, som ved overgangen til yngre romersk jernalder havde vokset sig stærk nok til at sætte sin indflydelse igennem. I lyset af at romerske importgenstande findes i relativt store mængder i grave fra ældre romersk jernalder, forekommer dette ikke usandsynligt. Et skatte- og retssystem forudsatte, at der eksisterede vasaller eller underordnede centre i det område, som centralmagten regerede i. Dette var nødvendigt for at kunne samle hirden, inddrive skatter og dømme i retsspørgsmål. ${ }^{4}$ Dette stemmer fint overens med redistribution af romerske importvarer til underordnede centre, hvor de kan have indgået i centralmagtens vareudveksling med disse.

\section{Handel og import i romersk og ældre germansk jernalder}

Betegnelsen romersk jernalder dækker over tidsrummet ca. 0 til ca. 375 e.Kr. I dette tidsrum er tilblivelsen af centre og deres tilbagegang karakteriseret ved henholdsvis tilstedeværelsen og fraværet af romersk import $\mathrm{i}$ grave og på bopladser. Romersk import findes især i gravene, men i den sidste del af perioden også på bo- og handelspladser. Danmark har i langt størstedelen af perioden en filterfunktion i forholdet til de øvrige områder i Skandinavien. Det vil sige, at visse typer af import "tilbageholdes« i det nuværende danske område og ikke videreformidles til det øvrige Skandinavien. I ældre romersk jernalder tegner Danmark sig således for $67 \%$ af den romerske import i Norden, imens tallet for yngre romersk jernalder er $63 \% .^{5}$

Formidlingen af importen sker i ældre romersk jernalder i flere led. Dette ses bl.a. ved, at der som følge af en filterfunktion i germanske centre nærmere ved den romerske rigsgrænse, Limes, er visse typer, der aldrig når til Norden, samt ved at der ikke er genstandstyper, som foretager et spring i udbredelse og for eksempel kun findes ved Limes og i Skandinavien. Denne måde at formidle importen på forandrer sig delvist i yngre romertid, hvor der går importveje fra Rhinen til Skandinavien, enten i form af omladepladser eller som direkte skibstrafik. ${ }^{6}$

I begyndelsen af romersk jernalder er den romerske import beskeden af omfang og træffes kun i få grave i Skandinavien. Dette billede ændrer sig markant ved overgangen til yngre romersk jernalder, hvor der opstår flere centre, og alle danske områder forsynes med fremmede prestigegenstande. Mængden af import forøges, og der er en stor mængde af masseproducerede, standardiserede varer. Der findes nu en glidende overgang i gravenes 
rigdom fra grave med en eller få importgenstande til virkeligt rige grave med store mængder import. Dette sker som følge af, at det redistributive system udvikles, så de høvdinge, der har erhvervet sig importerede genstande, bliver i stand til at videreformidle dem. Herved får en større del af eliten andel i importen.

Senere sker der en markant forøgelse i importens omfang, samtidig med at den rent geografisk begrænses til et par meget centrale områder på Østsjælland/Stevns og Sydøstfyn. Det er især importen af almindelige glastyper, der er stor, men også sjældne glas- og bronzekar udgør en stor del af importen.

I den senere del af romersk jernalder aftager importen i Danmark, en tendens der betyder, at der sker en udligning af forholdene, så de øvrige skandinaviske områder og Danmark nu er mere ligestillede, hvad angår mængden af import. Dog udøver Danmark stadig en vis filterfunktion i forhold til Norge og Sverige hvad angår typer, men ikke mængder. Der sker geografiske ændringer i udbredelsen af import, idet der er en begyndende tendens til, at Sydøstfyn overtager Østsjællands rolle som center. Det centrale område er dog fortsat Sjælland, men også Syd- og Vestnorge, Østersø-øerne og Mellemsverige har en central karakter.?

I slutningen af perioden er det Sydøstfyn, der er dominerende, og Jylland indtager en betydningsfuld position, imens Østsjellands rolle som center er udspillet. Der er nu mindre import i gravene. Dog opretholder Danmark stadig en filterfunktion, idet der er lige så mange sjældne glastyper i Danmark som i Norge, på trods af at Norge har tre gange så mange importførende grave.

I ældre germansk jernalder (375-550 e.Kr.) fortsætter tendensen med et center på Sydøstfyn, nærmere bestemt ved Gudme/Lundeborg. Sammen med pladser på Jyllands vestkyst udgør dette center en sydvestskandinavisk zone, som har sin modpol i en Østersøzone med tyngdepunkter på Öland, Gotland, Bornholm og på Helgö i Mellemsverige. Frankisk import erstatter sammen med sydøsteuropæiske genstande den romerske import, som er ophørt på dette tidspunkt.

\section{Gudme}

Gudme er en af de pladser, der i yngre romersk jernalder manifesterer sig stærkest som center. Gudme består af tre områder, kaldet Gudme I-III. Disse danner tilsammen den centrale boplads. Bopladsen består primært af gårdsanlæg fra yngre romersk og ældre germansk jernalder, men der er også påvist haller i Gudme, hvilket langt fra er normalt i romersk jernalder. Hallerne adskiller sig på flere måder fra den "normale« gårdsbebyggelse, blandt andet ved størrelsen, men også ved indretningen, idet de ikke har indeholdt stalde. Haller anses i denne periode for at være en stærk indika- 
tion på et center, fordi de sandsynligvis har været brugt til officielle formål, for eksempel kultmåltider og ceremonielle fester. Hele området omkring Gudme er rigt på ædelmetalfund, dette gæelder ikke mindst for centralbopladsen. Der er for eksempel fremkommet store mængder af romerske mønter samt brakteater, men andre genstande, blandt andet smykker, og mere tilfældige stykker af ædelmetal, blandt andet smeltet sølv og guld samt sølv- og guldafklip, forekommer også. Nogle af de ting, der adskiller Gudme fra »almindelige« jernalderbebyggelser, er altså: æedelmetal i store mængder, import i store mængder, halbygninger samt den tæette tilknytning til den store og rige gravplads Møllegårdsmarken og handelspladsen ved Lundeborg. Et andet specielt træk ved Gudmeområdet er de mange sakrale stednavne i området. Udover Gudme er der i området navnene Albjerg, Galdbjerg og Gudbjerg, hvor »al« betyder helligdom, og "gald" betyder offer. ${ }^{8}$ Disse sakrale stednavne tyder på, at området har været et stærkt kultcentrum i jernalderen.

\section{Lundeborg}

Ved opdagelsen af jernalderpladsen ved Lundeborg i 1986 blev det erkendt, at den adskilte sig fra samtidige bopladser på flere måder. For det første ved den kystnære beliggenhed lige ned til og på stranden ved udløbet af Tange $\AA$, for det andet ved de meget tykke kulturlag, og for det tredje fordi der ikke var tale om en almindelig agrarbebyggelse, men en sæsonmæssigt benyttet handels- og håndværksplads. ${ }^{9}$

Lundeborg er således den ældste dokumenterede handelsplads på dansk område. Aktiviteten på stedet strækker sig fra ca. 200 e.Kr. til ca. 800 e.Kr., og pladsen havde sin blomstringstid i de første ca. 200 år, det vil sige i romersk jernalder. ${ }^{10}$ Pladsen har været benyttet af mange forskellige håndværkere, blandt andet kammagere, guld- og sølvsmede, smede, træhåndværkere, samt muligvis en perlemager. Der har sandsynligvis også ligget et skibsværft på stedet. Ud over håndværk er der også påvist handel/udveksling af romerske importvarer.

Det tykke kulturlag på pladsen udviser talrige tegn på alle disse aktiviteter. Der er blandt andet fundet romerske mønter og andre romerske importgenstande samt diverse værktøjer til brug ved udøvelse af de forskellige håndværk. ${ }^{11}$

Der er som nævnt ikke tegn på tilstedeværelsen af traditionelle jernalderhuse på Lundeborg, men på den del af pladsen, der ligger syd for Tange $\AA ̊ ㇒$, er der konstateret spor efter hytter på $4 \times 5 \mathrm{~m}$ i form af lerblandede jordog sandgulve. ${ }^{12}$ Grunden til, at håndværkerne ikke bosatte sig permanent på stranden og byggede rigtige huse, har nok været, at de endnu ikke levede af deres håndværk, men derimod var bønder fra Gudme eller en af de andre landsbyer i området, eller måske omrejsende håndværkere med base 
længere sydpå. ${ }^{13}$ Dette bekræftes af mængderne af affald fra Lundeborg, som er for begrænsede til, at der kan have været tale om mere end en sæsonbebyggelse.

Lundeborgs centrale position forstås bedst i sammenhæng med pladsens nære tilknytning til Gudme. De to pladser ligger ikke ret langt fra hinanden, og det har sikkert været stormanden/høvdingen i Gudme, som har organiseret de årlige markeder i Lundeborg. ${ }^{14}$

Tilsammen udgør Gudme og Lundeborg samt gravpladsen ved Møllegårdsmarken et tydeligt markeret center fra ældre jernalder i Danmark. ${ }^{15}$

\section{Sorte Muld}

Sorte Muld er det meget sigende navn på en boplads fra yngre romersk og germansk jernalder beliggende på den nordøstlige spids af Bornholm. Bopladsen udviser tegn på almindelig agrarbebyggelse, men også væsentlige afvigelser fra en sådan. Der har været en bemærkelsesværdig stationær bebyggelse på Bornholm i forhold til de vandrende landsbyer, der ellers er normale for perioden i resten af Sydskandinavien. Det vides ikke, om dette skyldes de geografiske forhold, eller om det er resultatet af en afvigende samfundsstruktur. ${ }^{16}$ Sorte Muld bopladsen strækker sig i tid fra en spæd start i ældre romersk jernalder, over en betydelig vækst i yngre romersk jernalder til en kulmination i germansk jernalder efterfulgt af et ret brat fald i fundintensiteten og et totalt ophør i vikingetid. Der er foretaget en meget grundig udgravning af en lille del af bopladsen, hvor der blandt andet er anvendt vandsoldning og i udstrakt grad gjort brug af metaldetektorer, fordi der er mange fund af æedelmetal. Mange af disse genstande, f.eks. guldgubber, forekommer ikke i romersk jernalder, men de er alligevel interessante, idet de også er fundet på andre pladser, som har en kontinuitet tilbage i romersk jernalder, blandt andet Lundeborg.

Fundene, som gør pladsen speciel i forhold til den samtidige bebyggelse, er - udover guldgubberne - en stor mængde håndværksfund, især fra metalforarbejdning, samt fund af romerske mønter og andre importerede genstande som for eksempel glas. Herudover er der spor efter handel i form af vægtlodder. Pladsen kan have haft en funktion som kvægmarked på grundlag af de store mængder knogler af især kvæg og andre husdyr, men også af fisk. ${ }^{17}$ Sorte Muld udviser altså både nogle af de træk, som er karakteristiske for Gudme, for eksempel tegn på at pladsen har været høvdingesæde, og nogle, som mere er på linie med Lundeborg, især i form af spor efter handel og håndværk. Set i lyset af dette er det overvejende sandsynligt, at det er herfra redistributionen af prestigevarer til resten af øen er blevet organiseret. 


\section{Uppåkra}

Uppåkra ligner de tidligere beskrevne pladser på flere måder. For det første ved at den udviser en meget stor kontinuitet, og for det andet ved at den indeholder mange indikationer på at have været et center.

Pladsen ligger i Vestskåne, ca. 5 km syd for Lund på en slettestrækning afgrænset af det kuperede indland imod øst, havet imod vest, Höje Å imod nord og Sege $\AA$ imod syd. ${ }^{18}$

Området blev erkendt som værende en boplads i 1934, hvor der blev foretaget en begrænset udgravning, der afslørede omfattende kulturlag, flere steder mere end en meter tykke, med horisonter af sod/trækul, et stort fundmateriale i form af keramik og knogler samt genstande af jern og bronze. Der blev ved samme lejlighed fundet en grav i kulturlaget. Denne er ved hjælp af gravgodset dateret til yngre romersk jernalder. Yderligere findes der på en ås nogle hundrede meter øst for bopladsen en gravplads fra samme periode. ${ }^{19}$

Foreløbig er der påvist bopladsspor fra førromersk jernalder frem til ældre germansk jernalder, men der har også været aktiviteter på stedet $\mathrm{i}$ senere tidsrum, hvilket blandt andet ses af en stor mængde detektorfund fra yngre germansk jernalder og vendeltid. ${ }^{20}$

Fra 1930'erne til midt i 1990'erne er der ikke foretaget omfattende arkæologiske undersøgelser på pladsen, men den har alligevel været opfattet som en centralplads, måske for hele den sydvestlige del af Skåne. ${ }^{21}$ I midten af 1990'erne igangsatte man så projektet »Sammhällsstrukturen i Sydsverige under järnåldern«, som havde det som et af sine formål at placere Uppåkra i et mere detaljeret billede af Sydsverige. Dette medførte, at der blev iværksat væsentlige undersøgelser af pladsen blandt andet detektorundersøgelser og boreprøveundersøgelser, som skulle påvise pladsens geografiske og tidsmæssige udstrækning. ${ }^{22}$ Resultatet af detektorundersøgelsen har været en stor mængde genstande i bronze og æedelmetal. Antallet af jerngenstande, blandt andet værktøj, i pløjelaget har derimod været så omfattende, at det ikke var hensigtsmæssigt at foretage en systematisk eftersøgning efter disse genstande. Til sammenligning kan det nævnes, at andre skånske bopladser, som er blevet afsøgt med detektor i forbindelse med bygningen af Øresundsforbindelsen, i heldigste fald giver ca. ti bronzegenstande, hvilket kan give et fingerpeg om Uppåkras særstatus som kultplads. ${ }^{23}$

\section{Opsummering af pladsernes follestrcek}

Der er i alle de ovennævnte tilfælde tale om lokaliteter, som udviser en markant afvigelse fra de »normale« bebyggelser fra samme tidsrum. Pladserne er rige på importfund og andre genstande, som ligger ud over det, 
man må forvente at finde på en almindelig boplads, og de udviser alle tegn på håndværksproduktion. Derudover viser de i varierende grad tegn på handel og ophobning af rigdomme, samt tegn på kult. Det er især disse træk, som adskiller de nævnte pladser fra de almindelige bebyggelser, som er vigtige i denne sammenhæng. Supplerende oplysninger om de enkelte pladser vil blive givet undervejs, såfremt dette er nødvendigt.

\section{Centralpladsdefinition 1}

Denne definition tager udgangspunkt i, at det for at få et overblik over den magtpolitiske geografi er nødvendigt at identificere hvilke pladser, der har været almindelige bopladser og hvilke, der har været centrale i henholdsvis regional og overregional sammenhæng. Det indebærer en social og politisk niveaudeling af bopladserne på grundlag af det arkæologiske kildemateriale. Dette opnås i praksis ved at identificere de specifikke genstandstyper, der er karakteristiske for jernalderbopladser og inddele disse efter hvilken slags produktion, de er udtryk for.

Husholdsproduktion: Denne form for produktion er vanskelig at påvise arkæologisk, da det primært drejer sig om produktion af fødevarer og lignende til eget forbrug, det vil sige agerbrug, dyrehold, jagt og fiskeri. Rester efter en sådan produktion er ofte dårligt bevarede, og der er derfor ikke på nuværende tidspunkt basis for en repræsentativ fremstilling af forholdene omkring denne produktionsform.

Råvare- og dagligvareproduktion: Denne produktionsform består af produktion af genstande af jern, dvs. våben og redskaber, jern som råvare, smykker, tekstiler m.m. Der findes i følge forfatterne spor efter denne form for produktion på næsten alle typer af pladser.

Luksusvarer: Det drejer sig om de samme genstandstyper som i dagligvareproduktionen, men der er tale om mere værdifulde og luksusbetonede genstande.

Det er genstande fra de to sidstnævnte produktionsformer, der indgår i klassificeringen af de enkelte pladser som enten lokale pladser eller centralpladser med regional eller overregional betydning. ${ }^{24}$

Hvordan definition 1 anvendes, er illustreret i tabel 1 og 2, som viser, hvilke indikatorer på henholdsvis regionale og overregionale centre, der er til stede på de tre pladser Gudme/Lundeborg, Uppåkra og Sorte Muld.

Som man kan se af tabellerne, er der for alle tre pladsers vedkommende klare indikationer på regional betydning. På Uppåkra er tendensen dog ikke helt så entydig som på de to danske pladser, men dette skyldes muligvis den metode, der er anvendt på lokaliteten, hvor der ikke er foretaget en totaludgravning af bopladsområdet. 


\begin{tabular}{|l|c|c|c|}
\hline Tabel 1 & Gudme/Lundeborg & Uppåkra & Sorte Muld \\
\hline Solidi & $\mathrm{Ja}$ & & $\mathrm{Ja}$ \\
\hline Denarer & $\mathrm{Ja}$ & $\mathrm{Ja}$ & $\mathrm{Ja}$ \\
\hline Brakteater & $\mathrm{Ja}$ & & $\mathrm{Ja}$ \\
\hline Guldgubber & $\mathrm{Ja}$ & $\mathrm{Ja}$ & $\mathrm{Ja}$ \\
\hline Glas & $\mathrm{Ja}$ & $\mathrm{Ja}$ & $\mathrm{Ja}$ \\
\hline Brudguld & $\mathrm{Ja}$ & $\mathrm{Ja}$ & $\mathrm{Ja}$ \\
\hline Våben & $\mathrm{Ja}$ & $\mathrm{Ja}$ & $\mathrm{Ja}$ \\
\hline Statuettedele & $\mathrm{Ja}$ & $\mathrm{Ja}$ & $\mathrm{Ja}$ \\
\hline Rågranat & $\mathrm{Ja}$ & & $\mathrm{Ja}$ \\
\hline Metalskrot & $\mathrm{Ja}$ & $\mathrm{Ja}$ & $\mathrm{Ja}$ \\
\hline Støbeforme & $\mathrm{Ja}$ & & $\mathrm{Ja}$ \\
\hline Smeltedigler & $\mathrm{Ja}$ & $\mathrm{Ja}$ & $\mathrm{Ja}$ \\
\hline Jernbarrer & $\mathrm{Ja}$ & & $\mathrm{Ja}$ \\
\hline Jernslagge & $\mathrm{Ja}$ & $\mathrm{Ja}$ & $\mathrm{Ja}$ \\
\hline Forarbejder & $\mathrm{Ja}$ & $\mathrm{Ja}$ & $\mathrm{Ja}$ \\
\hline Oplysningerne er hentet fra; Thrane $1993, \mathrm{Watt} 1991$ og Helgesson \\
\hline \begin{tabular}{l} 
1998. \\
\hline
\end{tabular}
\end{tabular}

Tabel 1. Centralpladser med regional betydning. Oplysningerne er hentet fra Thrane 1993, Watt 1991 og Helgesson 1998.

Centres with regional significance. Based on information from Thrane 1993, Watt 1991 and Helgesson 1998.

\begin{tabular}{|l|c|c|c|}
\hline Tabel 2 & Gudme/Lunde-borg & Uppåkra & Sorte Muld \\
\hline Pragthjelme & & $\mathrm{Ja} ?$ & \\
\hline Kontinentale guldgenstande & $\mathrm{Ja}$ & $\mathrm{Ja}$ & $\mathrm{Ja}$ \\
\hline Usædvanlige fundkombinationer & $\mathrm{Ja}$ & $\mathrm{Ja}$ & $\mathrm{Ja}$ \\
\hline Genstande af høj kunstnerisk kvalitet & $\mathrm{Ja}$ & $\mathrm{Ja}$ & $\mathrm{Ja}$ \\
\hline \multicolumn{2}{|l}{} \\
\hline
\end{tabular}

Tabel 2. Centralpladser med overregional betydning. Oplysningerne er hentet fra Thrane 1993, Watt 1991 og Helgesson 1998.

Centres with super-regional significance. Based on information from Thrane 1993, Watt 1991 and Helgesson 1998.

Fordelen ved definition $1 \mathrm{er}$, at der opstilles klare kriterier for, hvornår en plads er central, og præcist hvor central den er. Dog er der flere helt væsentlige punkter i definitionen, som jeg ikke mener, der er redegjort tilstrækkeligt for.

For det første er det uklart, om alle genstandstyper i en kategori skal være til stede, før en plads tilhører denne kategori. For eksempel kan Uppåkra ikke opfylde alle kriterier for at være en centralplads på regionalt niveau, men der er vel ingen tvivl om, at den hæver sig over de jævne bopladser. Dette er problematisk, især fordi der heller ikke er klarhed om 
definitionerne af, hvad der er regionalt, og hvad der er overregionalt. Dette er det andet kritikpunkt. Der savnes en klar definition af, hvad disse begreber dækker over rent arealmæssigt. Hvad er en region i jernalderen? Er det en bygd? Eller er det en landsdel? Eller måske det, der svarer til et af de nuværende skandinaviske kongeriger? Der kan på sin vis argumenteres for alle tre muligheder; hvis en region svarer til en bygd, så må den største og/eller rigeste boplads i hver bygd være en centralplads med regional betydning. Hvis en region derimod (groft sagt) svarer til en landsdel, passer det fint med Sorte Muld på Bornholm, Gudme på Fyn, Dankirke på den jyske halvø, Feddersen Wierde i Nordvesttyskland og Uppåkra i Skåne. Og endelig kan man vel sige, at Gudme/Lundeborg, i hvert fald i en periode, har været den eneste overregionale centralplads, som har stået for redistribution af varer til resten af Skandinavien. Dette har selvfølgelig højst sandsynligt aldrig været tilfældet, men ud fra den måde, begreberne regionalt og overregionalt er defineret, er det faktisk muligt at opfatte fundmaterialet på denne måde. Begreberne regional og overregional betydning er altså ikke defineret grundigt nok.

Hvad angår de overregionale aspekter, så er de kriterier, der opstilles i definitionen, efter min mening alt for subjektive og dermed upræcise. Hvad er for eksempel »høj kunstnerisk kvalitet«? Og hvornår er en fundkombination usædvanlig? Især det første lægger op til, at den, som behandler fundet, også vurderer dets kunstneriske kvalitet, hvilket er næsten umuligt at gøre objektivt, fordi vi i dag befinder os i en helt anden kulturel kontekst end den, der har været gældende i jernaldersamfundet. Forudsat selvfølgelig at jernalderens mennesker overhovedet opererede med et begreb som »kunst«. En mere hensigtsmæssig formulering ville være »kunsthåndværk«. Et fjerde væsentligt kritikpunkt er, at definitionen forudsætter, at en enkelt plads er central i alle aspekter i samfundets organisation. Jeg mener ikke, at dette nødvendigvis er tilfældet, idet en plads efter min mening sagtens kan være en central kultplads uden nødvendigvis samtidig at være stærk handelsmæssigt, administrativt og militært. Det samme gør sig selvfølgelig gældende for de andre aspekter. Jeg mener ikke, at der er noget til hinder for, at de kan optræde uafhængigt af hinanden. Dette problem leder automatisk til det næste, nemlig om nogle aspekter af samfundets organisation er underrepræsenterede i modellen. Jeg mener, at modellen har en vis tendens til at skabe en overrepresentation af genstande, der forbindes med handel og håndværk. Dette kommer især til udtryk i den midterste sektion af pyramiden i kategorien med indikatorer for, at en plads har regional betydning (fig.1). Dog kan en underrepræsentativitet af nogle aspekter også være reel nok, idet der kan være sider af et samfunds sociale organisation, der simpelthen efterlader sig få spor i det arkæologiske materiale. Men for at man skal kunne finde disse underrepræsenterede områder, må en første betingelse være, at der ikke optræder andre former for 


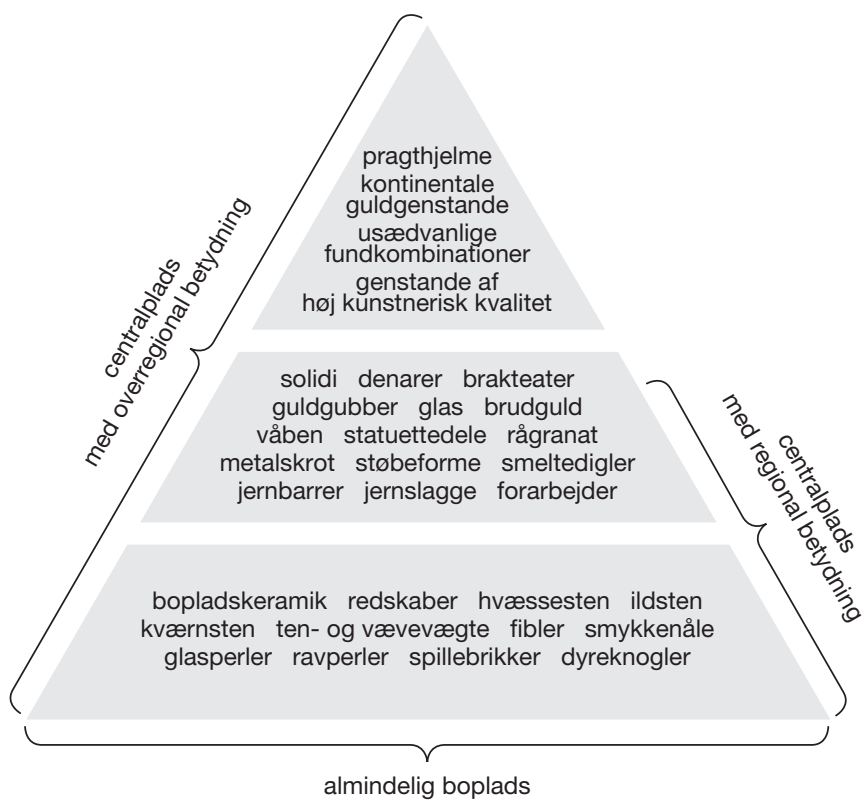

Fig. 1. Forsøg på niveaudeling af bopladsmateriale. Den trekantede form illustrerer, at der er flest af de almindelige bopladser, en nogenlunde bred basis af de regionale centralpladser og meget få af centralpladserne med overregional betydning. - Efter Fabech og Ringtved 1995.

Attempt to differentiate levels of settlements according to the find material. The triangular shape shows that most of the settlements are ordinary ones, while there is a reasonably broad range of regional central sites and there are very few centres with super-regional significance

dårlig repræsentativitet, det være sig overrepræsenterede eller underrepræsenterede områder.

Måske burde man i stedet for at tale om centralpladser tale om centralpladskomplekser eller centralbygder. Jeg tror, at dette ville give et mere detaljeret billede af magtstrukturerne i jernalderen, samtidig med at det ville forklare, hvorfor der er visse centralpladser, hvor nogle centrale aspekter af samfundsstrukturen ikke er dokumenteret, samtidig med at det vil skabe en bedre forståelse af lokaliteter som Gudme og Lundeborg, som tydeligvis har haft hver sin funktion, men som alligevel bærer præg af at være en del af den samme helhed.

Hvis man alene anvender definition 1 til at karakterisere bopladser som centrale eller ikke centrale, vil man fă et billede af samfundet, hvor nogle få pladser har en meget stærk central karakter, og hvor det store flertal af pladser overhovedet ikke har nogle indikatorer for centralitet. Det skaber et billede af et samfund, som lægger sig op ad en langt senere samfundsform, hvor alle centrale aspekter er samlet i købstæder, og hvor det store 
flertal af befolkningen lever afsondret fra de centrale funktioner. Imidlertid er der ikke meget, der tyder på, at der har eksisteret et sådant system i jernalderen. Tværtimod er det sandsynligt, at magten har været stærkt knyttet til én person mere end til et bestemt sted, hvilket vil fremgå af nedenstående definitioner.

\section{Centralpladsdefinition 2}

Denne definition ligner den første ved, at den bygger på en opdeling af bopladsmaterialet i tre kategorier, nemlig almindeligt bopladsmateriale, håndværksfund $\mathrm{og}$ specielle fund (handel og kult). ${ }^{25}$

Den første gruppe omfatter ifølge forfatteren de fundtyper, der knytter sig til en almindelig jernalderboplads, altså nogenlunde de samme genstandstyper som i definition 1 afspejler husholdsproduktion. Det antages, at disse genstandstyper ikke er tegn på specialiserede aktiviteter som for eksempel håndværk eller handel.

Den anden gruppe, håndværksfundene, er derimod karakteriseret ved, at de genstandstyper, der indgår i kategorien, har været anvendt til en produktion, som forudsætter en teknisk kunnen, som ikke alle i samfundet har haft.

Den tredje gruppe ses som tegn på, at der har fundet handel eller kulthandlinger sted på en plads. I denne sammenhæng lægges især vægt på guldgubberne, som er en meget markant fundgruppe på Sorte Muld. Disse tolkes som et udtryk for kulthandlinger. Vægtlodder og brudguld tolkes derimod som tegn på handelsaktiviteter og ligger sammen med det store knoglemateriale til grund for en formodning om, at Sorte Muldpladsen kan have haft en funktion som kvægmarked. ${ }^{26}$ Det er den anden og den tredje gruppe, der indikerer, at der er tale om en centralplads. Jo flere af de nævnte indikatorer, der er til stede, desto stærkere er tendensen til centerdannelse (fig. 2).

Definition 2 adskiller sig fra definition 1 ved udelukkende at bygge på en enkelt plads, og det ville derfor være meget nærliggende at benytte netop denne plads som eksempel på, hvordan teorien kan anvendes i praksis. Jeg har imidlertid valgt at bruge en anden plads til dette formål, fordi jeg mener, at det vil øge modellens troværdighed, hvis det viser sig, at den kan overføres til et andet materiale end det, den teoretisk bygger på.

Jeg har valgt at bruge Gudme/Lundeborg-komplekset til dette formål, fordi der er nogenlunde de samme indikationer på centerdannelse til stede her som på Sorte Muld, i hvert fald hvis bo- og kultpladsen ved Gudme og handelspladsen ved Lundeborg ses som en helhed, (tabel 3). 


\begin{tabular}{|l|l|l|}
\hline Almindeligt bopladsmateriale & Håndværksfund & Specielle fund (handel og kult) \\
\hline Bopladskeramik & Jernluppe og slagge & Solidi \\
\hline Diverse redskaber & & \\
\hline (knive m.m.) & Jernbarrer & Denarer \\
\hline Hvæssesten & Forarbejder (knive) & Brudguld \\
\hline Kværnsten & Smeltedigler & Vægtlodder \\
\hline Ten- og vævevægte & Støbeforme & Glas \\
\hline Sy- og vantenåle & Støberester & Cloissonne \\
\hline Benkamme & Metalskrot (bronze) & Rågranat \\
\hline Pincetter & Metalstempel & Guldgubber \\
\hline Fibler (lokalformer) & Patrice (metalblik) & Brakteat \\
\hline Smykkenåle & Guldblik & Mange lanser/spyd \\
\hline Glas- og ravperler & Rågranat & Statuettedele \\
\hline Spillebrikker & Uforarbejdet rav & \\
\hline Dyreknogler & Glas (skrot ?) & \\
\hline
\end{tabular}

Fig. 2. Oversigt over de vigtigste fundkategorier fra Sorte Muld. - Efter Watt 1991.

Overview of the most important find-categories from Sorte Muld.

\begin{tabular}{|l|l|}
\hline Håndværksfund & Specielle fund (handel og kult) \\
\hline Halvfabrikata (jern+bronze) & Denarer \\
\hline Mejsel, punsler og gravèrstikler & Solidi \\
\hline Træforarbejdningsredskaber (høvljern, skebor) & Klippeguld \\
\hline Affaldsprodukter fra skibsreparation (klinknagler) & Vægtlodder + vægtstang \\
\hline Slagger (fra jernstøbning) & Glas og terra sigillata \\
\hline Bronzebarrer & Guldgubber \\
\hline Glas (skrot, halvfabrikata og værkstedsspor) & Brakteater \\
\hline Uforarbejdet rav & Lanser/spyd \\
\hline Metalskrot & Statuettedele \\
\hline Affaldsprodukter fra bronzeforarbejdning & $\begin{array}{l}\text { Skattefund m. guldgenstande (smykker, } \\
\text { mundblik m.m.) }\end{array}$ \\
\hline Oplysningerne er hentet samme steder som i tabel 1 og 2. \\
\hline
\end{tabular}

Tabel 3. Opdeling af materialet fra Gudme/Lundeborg i håndværksfund og specielle fund (handel og kult). Oplysningerne er hentet fra Thrane 1993, Watt 1991 og Helgesson 1998.

Categorisation of the material from Gudme/Lundeborg into craft finds and special finds (trade and cult). Based on information from Thrane 1993, Watt 1991 and Helgesson 1998. 
Som det ses, er der omtrent de samme indikationer på håndværk, handel og kult til stede på de to pladser. Spørgsmålet er så bare, hvad det betyder i forhold til centralpladsernes indbyrdes hierarki?

Det står klart, at Margrethe Watt betragter Sorte Muld som det altdominerende center på Bornholm. Hun mener, at der i dette hovedcenter har været samlet kultplads, høvdingesæde og markedsplads på et ganske lille areal, og at dette har dannet udgangspunkt for en kontrol med hvilke genstande, der er gået videre til de andre mindre betydningsfulde centre på øen. ${ }^{27}$ Spørgsmålet er så bare, om denne definition kan overføres til Fyn? Umiddelbart skulle dette jo være endog meget sandsynligt, idet de topografiske forhold er nogenlunde de samme: en mellemstor $\varnothing$ med gode muligheder for kontakter mod både syd og nord. Hvis man kigger på et kort over fund fra yngre romersk og ældre germansk jernalder på Fyn, viser det sig, at der er fire-fem markante koncentrationer af fund, som indeholder romersk import eller guld fra ældre germansk jernalder. Disse er hovedsageligt begrænset til den østlige del af øen, og for yngre romertids vedkommende ses der yderligere en tendens til en overvejende sydlig udbredelse. ${ }^{28} \mathrm{Hvis}$ man antager, at disse fund indikerer placeringen af sekundære centre i forhold til Gudme/Lundeborg, er billedet ikke særligt afvigende fra den bornholmske situation, og der er basis for en sammenligning. Der er altså ikke noget i vejen for, at definitionen kan dække andre geografiske områder end Bornholm, men er definitionen i det hele taget anvendelig?

Definitionens største styrke er, at den er knap så »firkantet«som definition 1. Den opstiller blot visse fundgrupper, der er karakteristiske for pladser, hvor der er en tendens til centerdannelser, og jo flere karakteristiske fund, der er til stede, jo større er denne tendens. På denne måde undgår forfatteren at komme ind på begreber som regionale og overregionale centre, samtidig med at hun dog ikke udelukker en graduering i centerdannelsen.

Et af de største problemer med definitionen er, at den ikke er tilstrækkeligt klart formuleret, og at der ikke i den tekst, der danner udgangspunkt for teorien, er et klart teoretisk afsnit, hvor den forklares.

Herudover er definitionens opdeling af fundene i henholdsvis håndværksfund og specielle fund (handel og kult) uhensigtsmæssig eller nærmest vildledende. Jeg mener, at handel og håndværk er tættere forbundet end handel og kult, og at der derfor enten burde have været en opdeling $i$ fire kategorier (alm. bopladsmateriale, håndværk, handel, kult), eller at handel og håndværk tilsammen skulle have udgjort en kategori. Efter alt at dømme har det nemlig til dels været fra værkstederne, at produkterne er blevet forhandlet, i hvert fald på Lundeborg. Der er således ikke belæg for at slå de to fundgrupper handel og kult sammen, i hvert fald ikke uden at give en god forklaring, som dog savnes. Det nævnes ganske vist, at guld- 
gubberne kan have været en slags kultpenge, men derfra og til at sige, at de er udtryk for en regulær handelsrelateret aktivitet, er der et vel stort spring.

Grunden til, at opdelingen af fundene kan være vildledende, er, at det aldrig helt gøres klart, at forfatteren mener, at det er de enkelte fund, der kan rubriceres på denne måde og ikke de pladser, hvor de er fundet. For hvis en plads skulle kunne rubriceres som enten håndværks- eller handelsplads, hvad er så Lundeborg? At denne misforståelse kan opstå er endnu en god grund til, at der burde have været foretaget en klar redegørelse for den anvendte teori.

Det sidste svage punkt ved denne definition er, at den er udviklet med henblik på en enkelt plads. Dette bevirker, at det kan være svært at overføre den til andre lokaliteter og dermed at udlede noget om de fællestræk i samfundsorganisationen, der givetvis har eksisteret i dele af Skandinavien. Forfatteren nævner dog i en bisætning, at noget lignende kan gøre sig gældende for Sydøstsjælland og Fyn.

\section{Centralpladsdefinition 3}

Den tredje definition er meget anderledes end de to første, både hvad angår det rent metodiske: nemlig hvordan man udskiller et center og, i mindre grad, det teoretiske, nemlig hvad et center er. Definitionen er fremlagt af Kent Andersson i bogen »Samfundsorganisation og Regional Variation, Norden i romersk jernalder og folkevandringstid«. Hypotesen i denne teori er, at der ved hjælp af en analyse af guldgenstande kan skabes et overblik over tyngdepunktet i værkstedsaktiviteten og dermed en lokalisering af centrene. ${ }^{29}$ Der er dog efter forfatterens mening nogle faldgruber i denne teori, bl.a. at mængden af guldfund kan variere som følge af variationer i gravskik, økonomi og bevaringsforhold, samt at guldsmeden selv kan have indgået som objekt i en udveksling af prestigevarer, for eksempel som træl, eller på anden vis kan have flyttet sig fra plads til plads. ${ }^{30}$ Da det enkelte værksteds produkter kan være spredt over et større område som følge af en udveksling af prestigevarer, er det dog ikke nok at se på, hvor der er et tyngdepunkt $i$ antallet af guldfund. Man må studere den enkelte genstand for at finde tegn på, hvilket værksted den er fabrikeret i. Der findes i romersk jernalder en række guldrige regioner i Skandinavien inden for hvilke, der er ikke bare en større mængde genstande, men også en større mængde genstandstyper end i resten af Norden. Blandt disse områder udvælger forfatteren Gotland og Øland som studieområder. Herefter analyseres de fund, der menes at stamme fra værksteder på de to øer. Der er fortrinsvis tale om genstande, der er fundet lokalt på øerne, men også flere fund fra andre dele af Skandinavien inddrages. For Gotlands vedkom- 
mende er det perlerne, der studeres, og der drages den konklusion, at materialet er så ensartet, at der ikke kan peges på forskellige værksteder. ${ }^{31}$ For Ølands vedkommende er det granulations- og filigranornamenterede smykker, der studeres, fortrinsvis perler og berlokker. Det konkluderes, at der er tale om en selvstændig værkstedstradition på Øland, som dog har været under svag indflydelse fra Gotland. ${ }^{32}$

Herefter fortsætter forfatteren med en analyse af punsel-dekorerede genstande over hele Skandinavien. Han forsøger at afgøre, hvorvidt der er genstande med identisk ornamentering, som kan bestemmes som tilhørende samme værksted.

Jeg vil ikke forsøge at give et eksempel på anvendelsen af denne teori, da det kræver en helt speciel indsigt i guldsmedehåndværket samt et studie af de enkelte genstande, men blot nævne, at det kunne være interessant at se teorien anvendt med Gudme/Lundeborg, Himlingøje og Sorte Muld som primært studieområde.

Definition 3 har den klare fordel i forhold til definition 1 og 2 , at den ikke kun kan anvendes på bopladsmateriale, men også på guld fra grav- og depotfund. Dog har den også nogle åbenlyse svagheder, som især er et resultat af, at den kun bygger på genstande af et enkelt råmateriale, som oven i købet er meget eksklusivt og derfor meget følsomt overfor nuancer i samfundets organisation og resursetilførsel. Derudover giver definitionen ikke noget klart svar på, hvordan man udskiller forskellige niveauer i centerdannelsen, men antyder blot, at den tekniske/håndværksmæssige kvalitet af genstandene kan "have et provinsielt præg ${ }^{33}{ }^{33}$ Dette må betyde, at forfatteren går ud fra, at der har været dygtige guldsmede til stede på de mest centrale pladser og knapt så dygtige på de mindre centrale.

Sammenfattende vil definition 3 være et godt supplement til andre definitioner af centralpladshierarkisering, især vil den nok være velegnet til at støtte en eventuel formodning om en magtfuld persons tilstedeværelse på en given plads eller til at understøtte en teori om et knudepunkt i det system, der kontrollerer udvekslingen af prestigevarer. Derimod har definitionen lidt for mange faldgruber til, at den kan anvendes selvstændigt til at fastlægge eksistensen af en centerdannelse. Man vil kunne se, at der er tale om et center, idet guld formodentlig kun meget sjældent og i meget små mængder er nået ud til den almindelige bondebefolkning, men man vil ikke kunne vide hvilken slags center, der er tale om blot ved en analyse af det rent håndværksmæssige aspekt ved guldgenstandene. Guld indgår jo i mange af sfærerne i samfundet: som smykker, med det ene formål at vise rigdom og derigennem opnå prestige, som pynt på våben (mundblik), og som reelle statussymboler, for eksempel i form af ormehovedringene, som ifølge blandt andre Kent Andersson har været tegn på en bestemt, magtfuld stilling i samfundet, som måske kan have været slægtskabsbestemt. Alle disse aspekter af centerdannelsens natur går man glip af, hvis man udeluk- 
kende bestemmer centerdannelse ved hjælp af en teknisk analyse. Man kan altså godt ved hjælp af teorien finde ud af, om der er en centerdannelse, men denne centerdannelses natur kan man ikke sige noget om udelukkende ved hjælp af det håndværksmæssige. Dette vil selvfølgelig heller ikke ske i praksis, hvor man altid vil tage genstanden som helhed i betragtning og ikke bare se på dekoration og praktisk udformning, men det er alligevel et væsentligt problem, at teorien bygger på et grundlag, der er så snævert. Og selvom man tager genstandene som helhed med i sine overvejelser, er det stadig uhensigtsmæssigt at bygge en teori, der vedrører noget så vigtigt som centerdannelse, på et grundlag der er så spinkelt som genstande af ædelmetal.

Det, der overses i denne teori, er, at i de discipliner, som arkæologien er en del af, er helheden mere end summen af de enkelte dele. Derfor er det meget uheldigt at forsøge at etablere en forståelse af centerdannelse alene på baggrund af tekniske og håndværksmæssige detaljer på guldgenstande.

\section{Centralpladsdefinition 4}

Definition 4, som er opstillet af B. Helgesson, adskiller sig fra de tre førstnævnte definitioner ved, at den faktisk ikke opererer med en niveaudeling af centralpladserne, men derimod opstiller fire begreber, som viser hen til centrale aspekter af jernalderens samfund, og som kan bruges til at give et fingerpeg om, på hvilken måde et givent fund er centralt. ${ }^{34}$

Helgesson begynder med at stille spørgsmålet: „Hvad er centralt?» Dette besvarer han med, at alt det, som er fælles, eller som virker samlende for et vist område, er centralt. Det kan for eksempel være en handelsplads, religionen/kulten, den politiske styring eller bygaden i en landsby. ${ }^{35}$ Herefter opstilles så de fire begreber, som hver især er et aspekt af det, som karakteriserer «noget centralt«. De fire begreber er: Fænomen, Funktion, Lokalisering og Person.

Fanomen anvendes i teksten i betydningen »det, man opfatter«. De centrale fænomener i jernaldersamfundet er ifølge Helgesson: Lokalt styre, regionalt styre, overregionalt styre, håndværk/produktion, varebytte/ distribution, kult/religion, forsvar/krigsmagt, retsvæsen og kommunikation. Hvert fænomen udgør en enhed. Dette er nødvendigt, da en person/ et fænomen, der er overordnet i én sammenhæng, kan være underordnet $i$ en anden sammenhæng. For eksempel kan den, som udøver det lokale styre, være underordnet andre på et overregionalt plan. I virkeligheden har de ovennævnte fænomener dog ikke været helt uafhængige af hinanden, men det er nødvendigt at kunne afgrænse det enkelte fænomen for at kunne arbejde med materialet. ${ }^{36}$

Funktion anvendes i betydningen udrette, fremstille eller udøve. Hvert 
af samfundets fænomener har en primær funktion. For eksempel at styre en region, producere en vare eller at sørge for, at samfundets normer og regler følges. Nogle funktioner efterlader sig markante arkæologiske spor, for eksempel råvarer, redskaber eller restprodukter efter produktion af en vare, imens andre funktioner, for eksempel beslutningsprocesser, ikke efterlader sig arkæologiske spor.

Lokalisering hentyder til et konkret geografisk område. Der er i litteraturen en vis tendens til, at centrale fænomener tilknyttes en enkelt plads, men dette behøver ikke at være tilfældet i praksis. For eksempel er en høvding på rejse med sin hird ikke knyttet til en bestemt plads, men han er alligevel central, og det samme er den plads, han for tiden opholder sig på. Lokalisering kan altså både være en plads, flere pladser eller en region.

Person dækker over begreberne menneskelig tilstedeværelse eller individ. Personen kan være både det enkelte menneske, en gruppe af mennesker eller hele samfundet. Det er svært at udskille det enkelte menneske i det arkæologiske kildemateriale, og derfor må begrebet person kædes sammen med et arkæologisk fænomen og en funktion. Dette er nødvendigt, fordi den enkelte person kan have optrådt i mange roller og derved manifesteret sig i mange funktioner. Det kan være problematisk at forbinde et individ med et fænomen, fordi man ikke med sikkerhed kan vide, hvem der havde behov for at manifestere sig, og hvordan dette skete. Der er også kildekritiske problemer, idet det ikke altid er de mest veletablerede slægter, der markerer deres status stærkest i forbindelse med det enkelte individ, f.eks. ved en begravelse, hvorimod de, som befinder sig i en etableringsfase, ofte vil forsøge at markere deres status på denne måde.

Definition 4 er en del mere kompleks end de andre teorier, og det er derfor heller ikke så let at give et fyldestgørende eksempel på, hvordan den anvendes. Dog kan man opstille en tabel for hvilke spor, de forskellige fænomener har efterladt sig, hvilket er gjort for Uppåkras vedkommende på side 44 i Bertil Helgessons artikel.

Arkæologiske fænomener på Uppåkra-pladsen:

- lokalt styre - glas, fin keramik

- regionalt styre - guldgubbe, denarer

- overregionalt styre - pragthjelm?, kontinentale guldgenstande

- håndværk/produktion - digel, hornaffald

- vareudveksling/distribution - thürinsk fibula, romersk glas

- kult/religion - Odin-statuette, enkolpium

- forsvar/krigsmagt - sværdknap, lansespidser

- retsvæen - ?

- kommunikation - hulvej 
En lignende inddeling kan foretages med materialet fra Gudme/ Lundeborg:

- lokalt styre - glas, fin keramik

- regionalt styre - guldgubber, brakteater, romerske mønter

- overregionalt styre - kontinentale guldgenstande

- håndværk/produktion - se tabel 3

- vareudveksling/distribution - glas og anden romersk import, mønter, væegtstænger og -lodder

- kult/religion - brakteater, guldgubber, (sakrale stednavne)

- forsvar/krigsmagt - forskellige våben og tilbehør til våben

- retsvæsen - ?

- kommunikation - handelsplads

Det skal understreges, at ovenstående kun er et forsøg på at lave en inddeling af materialet fra Gudme/Lundeborg, som er sammenlignelig med den, der er foretaget for Uppåkras vedkommende. ${ }^{36}$ Under alle omstændigheder rummer den tabellignende måde at opstille materialet på den fare, at grundigheden må vige for overskueligheden. Mere om det i et senere afsnit.

Definition 4 har nogle klare fordele i forhold til de foregående definitioner. For det første er den mere dybdegående end de øvrige. Den kommer bedre ind på nogle af de aspekter i samfundet, som ellers har en tendens til at være underrepræsenterede i det arkæologiske materiale. Det gælder for eksempel retsvæsen og kommunikation, som normalt ikke efterlader sig væsentlige spor i det arkæologiske kildemateriale. Dette er selvfølgelig en stor fordel, idet det giver en større sammenhængende viden og et større overblik. Dog mister man hurtigt dette overblik igen, da den omfattende definition har en tendens til at fungere på mange niveauer samtidig, hvilket kan virke forvirrende. Man må mange gange gå tilbage for at se, om det nu er funktion eller fænomen, det pågældende afsnit behandler. Dog må det siges, at definition 4 er den af de hidtil gennemgåede definitioner, der kommer tæettest på at tage hensyn til alle forhold angående centralpladserne. En anden klar fordel ved definitionen er, at den ikke udelukkende er baseret på fund, med de andre kilder påhæftet som en slags sekundære kilder, men derimod medtager disse på linie med de regulære arkæologiske fund. Således er for eksempel beslutningsprocesser nævnt som en funktion på linie med håndværk/produktion. ${ }^{37}$

En anden stor fordel ved definitionen er, at den ikke direkte opererer med en niveaudeling af materialet, men lader overgangene være glidende, idet de enkelte funktioner og fænomener er adskilte enheder. Dette betyder, at man ikke kan identificere en plads som »centralplads med overregional betydning«, men blot fastslå, at denne plads har haft en betydning $\mathrm{i}$ en overregional sammenhæng i en eller flere af samfundets funktioner. En 
plads behøver altså ifølge denne teori ikke at have samme status indenfor alle samfundsforhold, men kan være selvstændig i nogle sammenhænge og underlagt andre pladser i andre sammenhænge. Dette er en fordel, fordi det giver nogle perspektiver, der bevæger sig væk fra den opfattelse, at alt det, som er centralt eller samlende for et samfund, nødvendigvis må befinde sig på samme sted. Hvilket er en etnocentrisk opfattelse, som udspringer af, at den arkæologiske forskning især foregår i samfund, der er præget af byer som de centrale enheder.

Det er positivt, at Bertil Helgesson i modsætning til de øvrige forfattere påpeger, at begrebet »centralplads« kan være misvisende, når det ureflekteret antages, at der er tale om en enkelt plads, som er central i alle sammenhænge. Det ville, som ovenfor nævnt, i denne forbindelse være ønskeligt at tale om centralbygder eller centralpladskomplekser. Eller måske skulle man nøjes med at tale om centrale aspekter i samfundet, og så lade den enkelte plads træde frem med den unikke kombination af centrale aspekter, der er til stede på netop denne plads.

En af de mere særprægede ting ved definition 4 er brugen af begrebet person. Der er ikke nødvendigvis noget i vejen for, at det indhold, Bertil Helgesson giver begrebet person, kan være en vigtig del af teoridannelsen vedrørende centrale samfundsaspekter, men selve ordet person er lidt misvisende. Det hentyder alt for ensidigt til et enkelt individ. Når Helgesson selv påpeger, at begrebet centralplads for entydigt hentyder til en enkelt plads, er det efter min mening ret påfaldende, at han vælger et begreb som person til at dække over et eller flere individer, som udgør noget centralt. Et forslag til et mere dækkende begreb kunne være »aktør«, hvilket også er et mere handlingspræget udtryk, som antyder, at det eller de individer, der omfattes af begrebet, faktisk foretager en bevidst handling.

En sidste ulempe ved definition $4 \mathrm{er}$, at den mangler noget til at samle de fire begreber. Der savnes noget, som kunne samle alle de oplysninger, man kan slutte sig til ud fra begreberne, til en helhed, en slags konklusion, om man vil.

\section{Centralpladsdefinition 5}

Ifølge Ulf Näsman er der to meget vigtige spørgsmål, der rejser sig, når man arbejder med begrebet centralpladser, nemlig:

- centralplads, ja - men central i hvad?

- central, javist - men på hvilken måde?

Disse to spørgsmål er væsentlige, idet mange af problemstillingerne vedrørende centralpladserne ændrer sig afhængigt af hvilken tolkningsmodel, man vælger. Fordi centralpladserne knytter sig til begreber, som både er til stede i meget komplekse samfund og i mindre komplekse, kan de optræede 
på et utal af måder, for eksempel er både en handelsplads (enkelt begreb) og en by (komplekst begreb) centrale i hver sit samfund. ${ }^{38}$ Det er meget vigtigt at stille sig selv de to ovenstående spørgsmål, hvis man virkelig vil forstå begreberne central, centralplads og centralpladshierarkisering. Det er vigtigt at forstå præcist hvad, hvilke begreber dækker over, hvis man skal gøre sig forhåbninger om at kunne bruge dem korrekt og dermed komme et lille skridt nærmere en troværdig teori om, hvordan jernalderens samfund var organiseret.

Hvad er det så, en centralplads er central i? Jeg har i begyndelsen af artiklen kort forsøgt at gøre rede for, hvordan man mener, at samfundet var opbygget i yngre romersk jernalder. Der er dog visse spørgsmål vedrørende denne samfundsstruktur, som ikke er afklarede. Et af disse spørgsmål er netop hvilken grad af centralisering, der var til stede. Det er vigtigt ikke at undervurdere jernaldersamfundet. Der er trods alt tale om et samfund, som efter alt at dømme har kendt til mange sider af romersk kultur, som $\mathrm{f}$. eks. et vægtsystem tilpasset det romerske. ${ }^{39} \mathrm{Jeg}$ mener således ikke, at der principielt er noget i vejen for, at der kan have eksisteret et samfund med en høj grad af centralisering og med ret store enheder i yngre romersk jernalder. Näsman nævner to mulige paralleller fra samfund med skriftlige kilder til den danske statsdannelse, nemlig den angelsaksiske og den merovingiske analogi.

Den angelsaksiske analogi tager udgangspunkt i, at der er mange små, ustabile samfund, som ligger i kamp med hinanden over lang tid. Der skabes overherredømmer, men de bryder hurtigt sammen igen. Til sidst lykkes det dog for et af de stærkeste småsamfund at erobre de andre et efter et, hurtigt efter hinanden, hvorefter en konge forener de små samfund i en egentlig rigsdannelse. I Danmark sker dette i vikingetid.

Den merovingiske analogi tager sit udgangspunkt i, at mange små stammesamfund smelter sammen, som tiden går, og herved opstår nye enheder. En sådan sammensmeltning leder til en mere eller mindre homogen ny samfundsenhed. Denne type samfund er imidlertid ikke så homogen, at man vil kalde det et kongerige, så derfor bruges betegnelsen stammeforbund. Først efter århundreder er disse nye samfund så faste, at man kan kalde dem kongeriger. Denne proces strækker sig fra romersk jernalder til vikingetid.

Problemet er så bare, at imens det er let nok at lave en hierarkisk opbygning, hvor man bygger niveauer af organisation ovenpå hinanden til et stammeforbund, er det knapt så let at placere centralpladserne indenfor de rigtige territorier. Det er svært at forbinde den rette centralplads med den rette region. Derfor bruger Näsman en teori af Renfrew, kaldet Peer Polity Interaction, forkortet PPI, hvilket kan oversættes til samspil imellem ligeværdige parter. Teorien tager udgangspunkt $\mathrm{i}$, at man isolerer et kulturelt set nogenlunde ensartet kulturområde, af Renfrew kaldet civilisation. In- 
denfor dette område vil der findes magtpolitisk adskilte regioner, som af Renfrew kaldes Early State Modules, forkortet ESM.

Det, som er karakteristisk for disse ESM, er, at forandringer hos en part hurtigt fører til tilsvarende forandringer hos de andre. Dette sker på baggrund af tre faktorer: rivalisering, efterligning og stigende omsætning af varer.

Rivalisering består dels af vold/krig, men også af forsøg på at fremkalde respekt fra naboerne for eksempel ved at holde imponerende bryllupper, udføre indviklede ritualer eller afholde ekstravagante fester.

Efterligning dækker over, at når noget for eksempel som følge af rivalisering indføres i et område, spredes det hurtigt til de omkringliggende områder.

Stigende omsætning af varer stimuleres af rivaliseringen og efterligningen, hvilket fører til et øget behov for institutioner, som kan håndtere handel og produktion. Her kommer centralpladserne ind i billedet, idet alt dette leder til en øget hierarkisering og forøget magtudøvelse fra elitens side.

PPI-modellen giver ikke nye oplysninger om samfundet i jernalderen, men kan hjælpe med til at systematisere iagttagelser og skabe klarhed om, hvad diskussionen om centralpladserne og deres hierarkisering egentlig handler om.

Efter at have gennemgået teorien forsøger Näsman at inddele det skandinaviske område i kulturer, idet han nævner, at det skandinaviske område som helhed er for stort, rent geografisk, til at udgøre en enhed. Disse kulturer forsøger han igen at inddele i ESM-områder (fig. 3).

Det ville i den forbindelse have været rart, hvis de centralpladser, der kendes, var sat ind i modellen, idet det kan virke lidt uoverskueligt med så mange regioner, som man ikke umiddelbart kan sætte et pladsnavn på. Dog er det naturligvis korrekt at lade være med at sætte enkeltpladser på teorien, hvis man mener, at det er regionerne i sig selv, der er interessante, og ikke de pladser, der findes indenfor dem. En anden svaghed er, at der ikke findes nogen forklaring på, hvilken plads der bliver den overordnede, eller om to centralpladser eventuelt bliver sideordnede, hvis to stammeområder slås sammen.

Hvis man tager udgangspunkt i den merovingiske analogi, tyder det på, at samfundet i yngre romersk jernalder har været præget af en mere eller mindre stabil udvikling, hvor stammer har slået sig sammen, og samfundet er inde i en periode, hvor der er gode betingelser for en styrkelse af den administrative organisation og dermed af centrene.

Hvis man derimod ser på den angelsaksiske analogi, vil der i yngre romersk jernalder have været et samfund, som var præget af ustabilitet og små skærmydsler stammesamfundene imellem. Dette passer godt nok med de mange krigsbytteofre fra perioden, men til gengæld ikke så godt med 


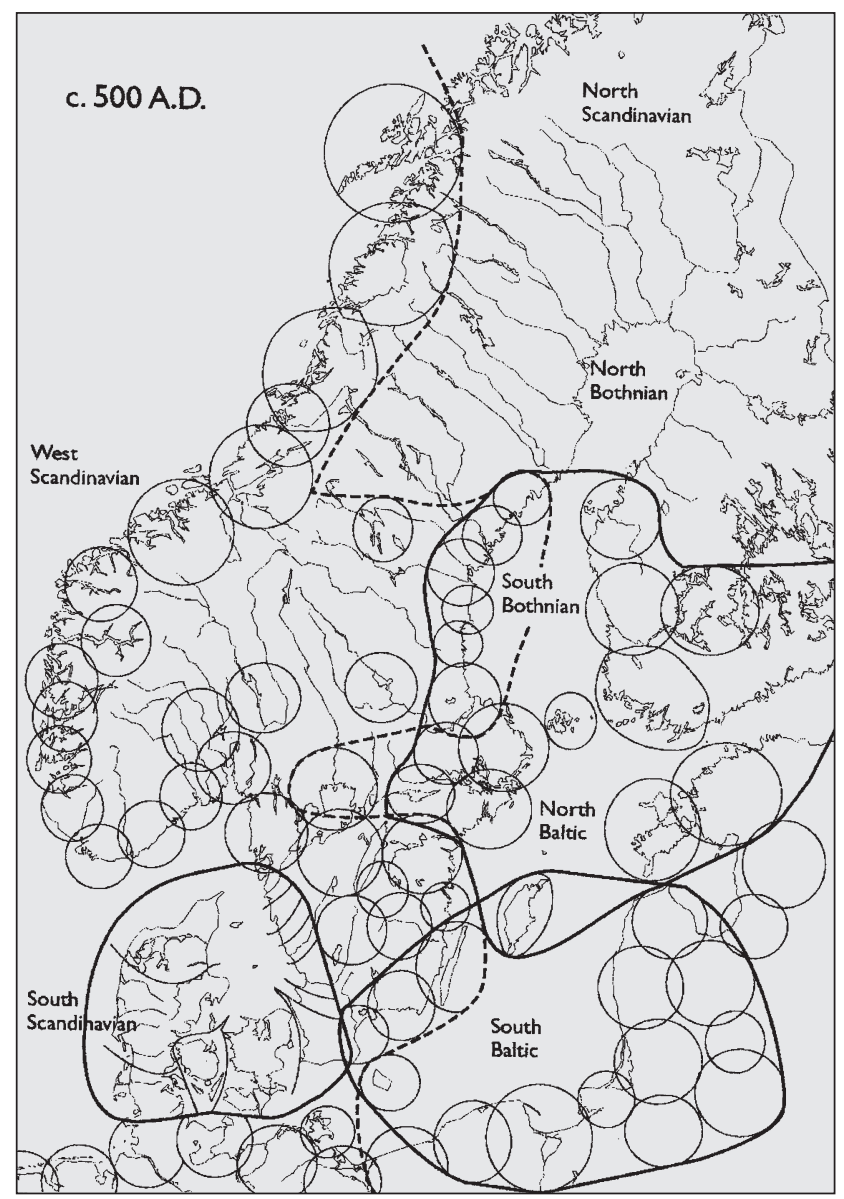

Fig. 3. Norden omkring 500 e.Kr. inddelt i regioner ca. svarende til Renfrews civilications. - Efter Näsman 1998.

Fig. 3. The Nordic region around $500 \mathrm{AD}$, divided into regions corresponding approximately to Renfrew's civilizations.

de overregionale centralpladser og deres ofte lange funktionstid, som tyder på, at der har været en vis stabilitet.

Hvis teorien skal anvendes på det sydskandinaviske område, sådan som Näsman foreslår, vil det komme til at passe med, at Uppåkra er centralplads for Skåne, Gudme/Lundeborg for Fyn og Dankirke for det mellemste eller sydligste Jylland. Resten af centralpladserne på overregionalt niveau i det sydskandinaviske kulturområde er måske lidt mere usikre, men det virker sandsynligt, at kortet er rigtigt inddelt.

Jeg mener, at centralpladsdefinition 5 er et meget ambitiøst og seriøst bud på en fyldestgørende definition på samfundsorganisation og dermed centralitet i yngre romersk jernalder i Sydskandinavien. Dog savnes der en fyldestgørende konklusion.

De klare fordele ved definitionen er, at den er grundig, at den tager udgangspunkt $i$ en velfunderet teori, og at den inddrager hele det nordiske 
område og ikke bare en enkelt plads. Herudover er det en klar fordel, at den inddrager andre aspekter af den politiske inddeling end bare centralpladserne i form af spørgsmålet om, hvad det er, centralpladserne er centrale i.

Ulemperne ved definitionen er, dels at den som nævnt ikke gøres ordentligt færdig, dels at den er så omfattende, hvilket bevirker, at den forekommer ret uoverskuelig. Det er ikke en model, man kaster et blik på, og så ved man nogenlunde, hvad den handler om. Et træk ved den, som kræver en vis varsomhed ved anvendelsen, er, at den bygger på analogier. Det betyder, at man skal være opmærksom på ikke at lade sig fastlåse af en af de to muligheder, definitionen giver for sammenligning. Man skal hele tiden være åben for andre muligheder end dem, som gives via analogierne.

Alt $i$ alt er definition 5 dog meget overbevisende, og den kan danne udgangspunkt for en endnu mere dybdegående og omfangsrig teoridannelse over emnet centralpladshierarkisering.

\section{Samlet vurdering af definition 1-5}

De fem ovenfor beskrevne definitioner vil i det nedenstående afsnit blive behandlet under et, idet det vil blive forsøgt analyseret hvorvidt og i hvilken udstrækning, de er brugbare i det videre arbejde med analysen af de forhold inden for samfundet, der senere førte til statsdannelse.

Generelt er det ikke ønskværdigt at opdele fundmaterialet i så stramme kategorier, som det sker ovenfor. Dels fordi der ikke foreligger tilstrækkelig viden om datidens samfund til at underbygge dette, og dels fordi der ikke nødvendigvis har været nogen skarp skelnen imellem niveauerne af centralitet. Jeg mener ikke, at det er ønskeligt eller praktisk muligt at tvinge det arkæologiske fundmateriale ind i den slags kasser, hvis man vel at mærke ønsker en nuanceret og korrekt fortolkning af jernalderens samfund. En klassificering med skarpt afgrænsede kategorier bør alene anvendes til at skabe et overblik over materialets omfang og geografiske spredning.

Overordnet set er der altså grund til at være skeptisk indstillet overfor en for "stram " teoretisering over centralpladshierarkiseringen. Det betyder dog ikke, at et sådant hierarki ikke er til stede, eller at det ikke er muligt at lave en inddeling af materialet, som tilgodeser både nuancer og overskuelighed.

Men hvad er det så, der er centralt i jernaldersamfundet? Og hvordan er det samfund opbygget, som dette "noget« er centralt i? Jeg selv mener, set i lyset af centralpladserne, at samfundet må have været nogenlunde stabilt, som det er beskrevet af Näsman. Der har sikkert været kampe, hvis der var uenigheder om for eksempel territorier eller lignende, men dette 
har næppe haft en grundlæggende indflydelse på samfundets opbygning, for hvis det var tilfældet, ville centralpladserne ikke udvise så langvarig en brug. Dette passer også fint med teorier i forbindelse med de mange våbenofferfund fra perioden om, at angriberne og forsvarerne ikke nødvendigvis var naboer, men at angriberne kunne komme både fra Norge og Tyskland. Noget sådant ville ikke være muligt, hvis et samfund ikke var organiseret på et rimeligt højt niveau. Det ville faktisk slet ikke være muligt at samle og organisere en hær bestående af så mange mænd, som moseofrene tyder på, der har været, hvis ikke der fandtes en velorganiseret samfundsstruktur, som kunne foretage den betydelige administration, det kræver at samle, udruste og kontrollere en sådan hær.

Centralpladserne har altså været centrale $\mathrm{i}$ et samfund, som har bestået af stammer og stammeforbund. De har været centrale i enheder, som har haft en udstrakt kontakt til hinanden. Om denne kontakt så har været fredelig eller ej, er et andet spørgsmål. Centralpladserne må altså antages at have fungeret som politiske centre på et højt organisationsniveau. Men er det så kun den enkelte centralplads i stammeområdet, der er central? Det mener jeg ikke. Der må have været pladser, som var centrale for større områder. Eller sagt på en anden måde, et stammeforbund må have haft en eller anden fællesnævner på et niveau, som er højere end bare den regionale stammehøvding. Det må have været denne fællesnævner, der har varetaget stammeforbundets forbindelser med områder længere væk, og det må også være herfra, at importerede luksusvarer er videredistribueret til de regionale stammehøvdinge. Denne fællesnævner kunne for eksempel være en plads som Gudme, som formentligt har fungeret på et plan, som rækker ud over det sydøstlige Fyn. Men hvordan lever de fem omtalte teorier så op til det, de lover, nemlig en teoridannelse vedrørende centralpladserne og centralpladshierarkiseringen?

For at besvare dette spørgsmål er det først og fremmest nødvendigt at finde ud af, hvilke fakta de fem definitioner bygger på og derefter at se på, hvilke antagelser fra forfatternes side disse fakta er koblet med. De fakta, der ligger til grund for de fleste definitioner vedrørende centralpladshierarkisering, er først og fremmest det arkæologiske kildemateriale. Den del af det arkæologiske kildemateriale, der ligger til grund for definitionerne, består overordnet set af bopladser, gravpladser, handelspladser og skattefund. Fra disse fund er det muligt at udlede visse teorier om samfundets opbygning og den sociale struktur, herunder at forsøge at fastslå hvor der har været dannet centre, og at forsøge at udlede hvor centrale disse lokaliteter har været.

Ud over det arkæologiske kildemateriale er der visse andre faktorer, der kan hjælpe med til at fastslå et centers placering. Disse faktorer tager blandt andet udgangspunkt i den kontinuitet, der er til stede på visse af lokaliteterne. Således kan stednavne af religiøs eller organisatorisk art, samt en 
kontinuitet op til vikingetid eller tidlig middelalder i form af en mulig etablering af en kirke i tilknytning til vikingetidens stormandsgård, være fingerpeg om, at der har eksisteret et center på stedet i forhistorisk tid. ${ }^{40}$ Disse fakta er dog kun en hjælp til at fastslå, at der har været et center, hvis arkæologerne allerede har en mistanke om, at dette er tilfældet. De er altså ikke i sig selv beviser på en forhistorisk centerdannelse, men de kan være medvirkende til at bestyrke formodningen om, at en sådan har fundet sted.

En tredje type af informationer, som bruges i teoridannelsen vedrørende centralpladshierarkisering, er teorier, som viser, hvordan et høvdingesamfund eller en tidlig stat er opbygget, som for eksempel teorierne i bogen "Archaeology - Theories, Methods and Practice « af Colin Renfrew og Paul Bahn.

Det gennemgås her, hvordan man kan identificere centre i høvdingedømmer eller tidlige stater. Det bedste kildemateriale er i denne forbindelse skriftlige kilder. Disse er ikke til stede i dette tilfælde. Derfor må man i stedet kigge på graden af social organisation. Den lokalitet, hvor den sociale organisation er mest kompleks og ligner centrene i de omkringliggende samfund mest, er så det primære center. I den forbindelse løber man igen ind i vanskeligheder med de centre, vi her har med at gøre. Det er jo ikke bare et enkelt center, der skal lokaliseres, men derimod en type af centre indenfor et forholdsvist selvstændigt kulturområde, så denne metode kan heller ikke fuldt ud anvendes. Hvor dette ikke kan lade sig gøre, foreslår Renfrew \& Bahn, at man forsøger at lokalisere bygninger af verdslig eller gejstlig karakter, som udviser tegn på regelbundethed, eller som har en karakter, som tydeligt adskiller sig fra den "normale « bebyggelse. ${ }^{41}$ Det kunne for eksempel være hallerne, som de findes i Gudme. Hvor dette heller ikke er muligt, skal man ifølge de to forfattere lede efter genstande, som kan tyde på en centerfunktion. Det kunne i det aktuelle tilfælde være importgenstande, mønter, vægtlodder eller genstande af ædelmetal. Andre muligheder er at lede efter befæstninger eller møntsteder i de kulturer, hvor der har været en økonomi, som tillader dette. Som man kan se, er det især genstandene, der bruges i det aktuelle tilfælde, mens de andre typer af informationer tages til hjælp, hvor de er tilgængelige.

\section{Definitionernes anvendelighed}

Men hvad så, når det, der formodes at være et center, er lokaliseret? Er arkæologernes opgave så slut? Eller må vi »skrælle« endnu et lag af materialet og prøve at nå ind til det, der ligger til grund for den måde, de centrale pladser er udformet på, og årsagerne til at centrene overhovedet opstod. 
Det er et faktum, at der, i det der nu er Danmark, i yngre romersk jernalder har eksisteret en form for central magtfaktor, som har været stærk nok til at organisere markeder og tiltrække importerede luksusgenstande. Men hvilken form, denne centrale magtfaktor har haft, vides ikke med sikkerhed. Dog antages det, at der har eksisteret en række økonomisk og politisk uafhængige enheder, der af nogle arkæologer benævnes småkongedømmer, af andre høvdingedømmer, og at det er inden for disse, at denne magtfaktor skal lokaliseres. Men skal den lokaliseres til en enkelt plads? Eller eventuelt til en eller flere personer? Som det ses af de gennemgåede definitioner, er der stor uenighed om dette.

Det samfund, forskerne vil analysere ved hjælp af definitionerne, er et samfund, som er baseret på jordbrug. Langt hovedparten af befolkningen har alene ernæret sig ved at udnytte jorden, både til landbrug og kvægbrug og til for eksempel jagt og fiskeri, som har fungeret som supplement. Der har været tale om et samfund, som har organiseret sig i landsbyer, som netop på denne tid begynder at bestå af klart selvstændige gårde. ${ }^{42}$ Der er etableret en central magt, som har tilstrækkelig indflydelse til at tiltrække import ved at have relationer sydpå, og ved at have noget at tilbyde til gengæld for de værdifulde genstande, og som har magt nok til at disponere over en velordnet hær, en hird. Denne hird har blandt andet efterladt sig spor i form af de store våbenofferfund fra perioden, hvor det tydeligt fremgår, at den tabende part, hvis udstyr er havnet i mosen, har været en velordnet, ranginddelt hær. Går man ud fra, at det er indtrængende hære, der er blevet besejret, er det sandsynligt, at den hird, der har slået dem, har været mindst lige så velorganiseret, som den tabende part. Tilstedeværelsen af en hird viser også, at der er blevet kæmpet om den politiske kontrol over visse vigtige resurser, det kan være adgangen til råvarer (myremalm), strategisk vigtige lokaliteter eller simpelthen jord. For at der kan eksistere en hær, er det nødvendigt at kunne finansiere den. Hæren bestod af lokale vasaller eller høvdinge og deres hird. Disse høvdinge har været nødsaget til at opkræve tribut eller skat for at kunne finansiere hirden. For at kunne opkræve den slags skatter har det været nødvendigt med en vis administration.

Der er altså klare tegn på, at der har været en central magt til stede i yngre romersk og germansk jernalder. Som nævnt er spørgsmålet hvilken udformning, den har haft. Har der været tale om en slags kongemagt i et begrænset område, hvor det har været kongen som person, der har været det centrale, og hvor magtens centrum derfor har været afhængig af, hvor han opholdt sig på et givent tidspunkt? Eller har der været tale om et system, hvor lokale høvdinge havde magten i kraft af, at de havde deres magtbase i en stærk landsby/centralplads?

Jeg mener ikke, at det er muligt at fastslå, om der altid har været en enkelt plads, der har styret udvekslingen af varer, kulten og andre centrale 
aspekter af samfundet i det område, der har været under kontrol af den lokalt tilstedeværende magtfaktor. På den ene side set er der ikke noget i vejen for, at noget sådant er tilfældet. For eksempel er skattefundene omkring Gudme en indikation på, at der har været en meget stærk magtfaktor på netop denne lokalitet, ligesom de mange importførende grave på Møllegårdsmarken kan give et fingerpeg om, at den magtfaktor, som har været styrende i forbindelse med importen i området, har været til stede på den samme plads i længere tid. Dog er der også i Gudme tegn på, at det ikke er den samme plads, der er udgangspunkt for alle de dele af samfundslivet, der kan betragtes som centrale. Det mest oplagte er handelspladsen ved Lundeborg, som jo er en væsentlig grund til, at Gudme er så speciel en lokalitet, og som godt nok højst sandsynligt har været styret fra Gudme, men som ikke konkret befinder sig på eller i umiddelbar nærhed af centralbopladsen.

På andre lokaliteter end Gudme er forholdene endnu mere tvetydige. På Sorte Muld er der således spor efter håndværk, handel og kult, men der er ingen gravplads i nærheden med importførende grave, som kunne være et tydeligt fingerpeg om, at det var her, eliten holdt til, ligesom der ikke er konstateret spor efter halbygninger. Det må dog antages, at det har været her, eliten har etableret sig, hvilket ses af de rige fund, men på en plads, hvor dette ikke var bevaret, ville det ikke have været muligt at se, hvorvidt der rent faktisk havde været en magtfaktor til stede på pladsen i form af en magtfuld enkeltperson.

Den mest grundlæggende antagelse i de ovennævnte teorier er, at der har eksisteret et net af underordnede centre eller vasaller, som har været underlagt kontrol fra det overordnede center. Dette ses ifølge flere forfattere blandt andet ved en udbredelse af importen fra det overordnede center til de underordnede, og det er netop denne antagelse, der ligger til grund for selve begrebet centralpladshierarkisering. Man kan så diskutere, om det er rigtigt, at der i et givent område har eksisteret $e t$ overordnet center og flere underordnede, eller om der snarere har været tale om, at der har været et center, der har styret visse aspekter af samfundslivet, som er meget synlige i det arkæologiske kildemateriale, og at de andre centre har været styrende $\mathrm{i}$ andre anliggender, for eksempel retsvæsen eller andre ting, som er svære at dokumentere arkæologisk, eller om de underordnede centre har været selvstændige enheder i visse anliggender og kun underordnet det overordnede center i andre, meget centrale anliggender.

Man kan i den forbindelse spørge sig selv om, hvorvidt det er sikkert, at det som er centralt, er en helhed, som definition 1,2,3 \& 5 går ud fra, at det er, eller om der snarere er tale om uafhængige fænomener, som definition 4 taler for. En antagelse som den første, at det centrale er en helhed, er farlig, fordi det betyder, at hvis nogle, men ikke alle centrale aspekter er til stede på en plads, så er den svær at anerkende som værende af overord- 
net betydning. Det er vel muligt, at en plads kan være af overordnet betydning i nogle sammenhænge, selvom den ikke nødvendigvis er det $\mathrm{i}$ alle.

\section{Konklusion}

Som konklusion på, hvad det er, der er centralt, og hvad en centralplads egentlig er, ville det letteste være at følge de forslag, som allerede foreligger, således at man opbyggede et hierarki, hvor der var en lokalitet, som var den endegyldigt mest centrale, og som videredistribuerede genstande til lokaliteter, som var mindre centrale. Dette er dog langt fra det mest korrekte. Hvis man skal bruge de definitioner, der foreligger på nuværende tidspunkt, er det vigtigt, at de bruges til at inspirere og supplere hinanden i stedet for at modbevise hinanden.

Hvis man således bruger definition 1 til at opnå et overblik over, hvilket niveau en konkret plads befinder sig på ud fra fundmaterialet, og derefter forsøger at tolke hvilke fænomener og funktioner, der har været til stede ved hjælp af definition 4 for til sidst at indpasse dette $\mathrm{i}$ et større perspektiv ved hjælp af definition 5, mener jeg, at man er godt på vej til at danne sig et billede af en konkret plads, som både har overblikket fra definition $1 \mathrm{og}$ grundigheden fra definition 4 og 5 .

Centralpladser som begreb er meget varierede, både i tid, rum og arkæologisk materiale. Det er derfor, det er så svært at teoretisere over dem. Men samtidig med at de er uensartede og meget varierende, er de utrolig spændende. Det er vel også derfor, det er så fristende at væve dem ind i et net af teorier. Jeg mener dog, at man måske burde holde sig til at teoretisere over den samfundsopbygning, som ligger til grund for de lokale magtmonopoliseringer, som centralpladserne er udtryk for og så indpasse hver enkelt plads i denne teori på grundlag af det unikke kildemateriale, der er til stede netop der. Måske vil man derved kunne undgå at "tvinge" materialet til at afgive informationer, det ikke indeholder, og samtidig kunne frigøre sig fra den tilbøjelighed, arkæologer kan have, til at ville gøre alting op i håndfaste genstande og lokaliteter. Med en lidt letkøbt analogi kan man jo sige, at det i nutidens magtpolitiske spil ikke er Christiansborg, der er det vigtige, men de politikere, der bruger det som ramme for magten. På samme måde er det med centralpladserne. De kan sige meget om, hvor magten har haft sit centrum, men ikke så meget om hvilken form, magten har taget. 


\section{NOTER}

1. Lund Hansen 1988.

2. Lund Hansen 1988, s. 88-89.

3. Hedeager 1990, s. 201.

4. Hedeager 1990, s. 203.

5. Lund Hansen 1988.

6. Lund Hansen 1988.

7. Lund Hansen 1988.

8. Kromann m.fl. 1991, s. 154.

9. Thomsen m.fl. 1993.

10. Kromann m.fl. 1991, s. 150.

11. Thomsen m.fl. 1993, se i øvrigt tabellen i afsnittet »Centralpladsdefinition 2 «.

12. Thomsen m.fl. 1993, s. 94.

13. Thomsen m.fl. 1993, s. 95.

14. Thomsen m.fl. 1993.

15. Thomsen m.fl. 1993.

16. Watt 1991, s. 89.

17. Watt 1991, s. 93, 105.

18. Larsson 1998, s. 95-6.

19. Larsson 1998, s. 97.

20. Larsson 1998, s. 97.

21. Larsson 1998, s. 100.

22. Larsson 1998.

23. Larsson 1998.

24. I bogen "Produksjon og samfunn" er der taget udgangspunkt i ældre germanertid, men der er brugt eksempler fra Gudme, som også har gyldighed for yngre romertid.

25. Watt 1991, s. 93.

26. Watt 1991, s. 05.

27. Watt 1991, s. 5.

28. Fabech 1991, s. 176.

29. Andersson 1989, s. 213.

30. Andersson 1989, s. 218.

31. Andersson 1989, s. 220.

32. Andersson 1989, s. 222.

33. Andersson 1989, s. 123, 126.

34. Helgesson 1998 s. 39-40.

35. Helgesson 1998, s. 39.

36. Der er selvfølgelig nogle fejlkilder, idet der ikke foreligger en samlet, publiceret fortegnelse over fund fra Gudme, hvilket selvfølgelig resulterer i, at visse fundgrupper kan være udeladt. Men hvis ovenstående blot betegnes som en oversigt over de væsentligste fundgrupper, der kan henføres til et givent fænomen, skulle inddelingen være god nok.

37. Helgesson 1998, s. 40-1.

38. Helgesson 1998, s. 41.

39. Näsman 1998.

40. Kromann m.fl. 1991.

41. Fabech \& Ringtved 1995.

42. Renfrew \& Bahn 1996, s. 196.

43. Hedeager 1990, s. 201. 


\section{LITTERATUR}

Andersson, Kent 1989: Skandinaviens guldfynd från romersk tid som indikatorer på politiska och/eller ekonomiska centra. I: Charlotte Fabech og Jytte Ringtved (red.): Samfundsorganisation og Regional Variation, Norden i romersk jernalder og folkevandringstid. Beretning fra 1. nordiske jernaldersymposium på Sandbjerg Slot 11.-15. april 1989. Jysk Arkæologisk Selskabs Skrifter XXVII, s. 213-231. Højbjerg.

Fabech, Charlotte 1991: Reading Society from the Cultural Landscape. South Scandinavia between Sacral and Political Power. I: P.O. Nielsen, Klavs Randsborg og Henrik Thrane (red.): The Archaeology of Gudme and Lundeborg. Papers presented at a Conference at Svendborg, October 1991. Arkæologiske Studier vol. X, s.169-183. København.

Fabech, Charlotte og Jytte Ringtved 1995: Magtens geografi i Sydskandinavien. Om kulturlandskab, produktion og bebyggelsesmønstre. I: H.R. Gjørstein (red.): Produktion og sammfunn, Varia 30. Universitetets Oldsakssamling, s. 11-31. Oslo.

Hansen, Ulla Lund 1988: Handelscentre i Danmark i romersk og ældre germansk jernalder. I: Aage Andersen (red.): Festskrift til Olaf Olsen på 60 års dagen d. 7. Juni, 1988, s. 79-90. København.

Hedeager, Lotte 1990: Danmarks jernalder - Mellem stamme og stat. Århus.

Helgesson, Bertil 1998: vad är centralt? - fenomen och funktion; lokalisering och person. I: Lars Larsson og Birgitta Hårdh (red.): Centrala platser. Centrala frågor. Samhällsstrukturen under Järnåldern. En Vänbok til Berta Stjernquist. Acta Arcaeologica Lundensia nr. 28. Lund.

Kromann, Anne, Poul Otto Nielsen, Klavs Randsborg, Peter Vang Petersen og Per O. Thomsen 1991: Gudme og Lundeborg - et fynsk rigdomscenter i jernalderen. Nationalmuseets Arbejdsmark 1991, s. 144-160.

Larsson, Lars 1998: Gjort och ogjort i Uppåkra. I: Lars Larsson og Birgitta Hårdh (red.): Centrala platser. Centrala frågor. Samhällsstrukturen under Järnåldern. En Vänbok til Berta Stjernquist. Acta Arcaeologica Lundensia nr. 28. Lund.

Näsman, Ulf 1998: Sydskandinavisk samhällsstruktur I ljuset av merovingisk och anglosaxisk analogi eller i vad är det som centralplatserna är centrala? I: Lars Larsson og Birgitta Hårdh (red.): Centrala platser. Centrala frågor. Samhällsstrukturen under Järnåldern. En Vänbok til Berta Stjernquist. Acta Arcaeologica Lundensia nr. 28, s. 1-26. Lund.

Renfrew, Colin \& Paul Bahn 1996: Archaeology - Theories, Methods, and Practice. 2. udgave, s. 195-206. London.

Thomsen, Per O., Benno Blæsild, Nis Hardt og Karsten Kjer Michaelsen 1993: Lundeborg - En handelsplads fra jernalderen. Skrifter fra Svendborg og Omegns Museum, bind 32. Svendborg.

Watt, Margrethe 1991: Sorte Muld. Høvdingesæde og kultcentrum fra Bornholms yngre jernalder. I: Peder Mortensen og Birgit M. Rasmussen (red.): Fra Stamme til Stat i Danmark 2. Høvdingesamfund og Kongemagt. Jysk Arkæologisk Selskabs Skrifter XXII:2, s. 89-107. Højbjerg. 


\section{Centres in the Roman Iron Age}

During the last $10-15$ years, a number of new sites from the Roman Iron Age have been found throughout Southern Scandinavia. These sites are different from the standard agricultural settlements of the period, in that they contain structures and objects testifying to greater resources and to contacts with areas more deeply affected by Roman culture. These centres have cleared the path for a new understanding of Iron Age society. It is now commonly accepted that the centres of the Roman Iron Age were the predecessors of the structure which formed the basis of the kingdom - and subsequently the state - of Denmark during the Viking Age. On this basis one might expect that there would be a thoroughly tested codex of how to describe what happened during this development in society. However, this is not the case. The purpose of this article is to try to outline the advantages and disadvantages of some of the terms and concepts used in this field of research. And at the same time to explain what it is that happens in the Roman Iron Age that is of interest in relation to the formation of the state in the Viking Age.

The most rudimentary definition of a centre is that it is a site that shows signs of having a function which has been of importance to people in an area larger than the territory of the site itself. There are, of course, different levels on which a site can be a centre. Some sites may have been of importance only to the nearest neighbouring sites, while others may have dominated an entire region.

This article primarily concerns the centres which have been of importance to a relatively large group of people scattered over a large area. This is due to the fact that these sites are easier to recognise as centres. They are the ones containing the most exceptional and varied material, including inter alia Roman imports.

The first theory to be evaluated is proposed by Charlotte Fabech and Jytte Ringtved in the book Produksjon og samfunn". This theory advocates that to obtain an overview of the geography of power during the Iron Age it is necessary to identify which sites were normal agricultural units and which were centres on a regional or super-regional level. This involves dividing the sites into social and political levels based on the archaeological evidence. This is done by identifying specific types of items and dividing them into levels based on the level of expertise needed to produce them (fig. 1) (tables 1-2).

The second theory to be evaluated is proposed by Margrethe Watt in an article concerning the site "Sorte Muld" in the book "Fra Stamme til Stat 2". It is similar to the first theory, in that it relies on dividing the evidence into 3 categories. In this case common material, material containing evidence of crafts and material of an exceptional character (fig. 2) (table 3).

The third theory is very different from the two first ones, both with regard to method (how to establish whether a site is a centre), and, to a lesser degree, with regard to concept (what is a centre?). This theory is proposed by Kent Andersson in the book "Samfundsorganisation og Regional Variation, Norden i romersk jernalder og folkevandringstid". The hypothesis is that by analysing gold objects it is possible to find out where they have been manufactured, and thereby to find the centres from which they originate.

The fourth theory is proposed by Bertil Helgesson in the book "Centrala Platser-Centrala Frågor".

This is very different from the other theories, in that it does not operate with different levels of centres. Instead it operates with four aspects of centrality in Iron-Age society. The four aspects are: phenomenon, function, localisation and person.

According to Ulf Näsman and the fifth 
theory, there are two questions which are important when working with centres. These questions are:

- Centre, yes - but central in what?

- Centre, yes - but in what way?

These two questions are important, since many of the problems concerning the centres change aspect depending on which interpretation is chosen (fig. 3).

In general terms, it is not desirable to divide the material into categories which are as tight as the theories proposed above, because it is not certain that there were abrupt divisions between different levels of centrality. This is a matter of purely subjective judgement and as such it is neither desirable nor possible to force the archaeological material into this type of frame - if it is an objective and complex interpretation of Iron Age society which is the goal. On the other hand, there is nothing wrong with using a tight classification to create an overview of the volume and geographical distribution of the material.

But then what happens when the centre is identified? Is the task of the archaeologist completed? Or should we try to "peel off" another layer to try to find out what lies behind the way the centres appear, and why they evolved in the first place?

It is a fact that in what is now Denmark, a central power existed in the Roman Iron Age. A central power strong enough to organise markets and attract imported luxury goods. But how this central power was organised is still an open question. It is not possible to determine whether there was always a single site that controlled the exchange of products, cult and military activities, and other central aspects of society in an area controlled by a local power-force. On the other hand, there is nothing to indicate that this was not the case. For instance the situation in the Gudme area indicates that a figure of power located on the
Gudme site was responsible for both the market at Lundeborg, the cult activities indicated by the place-names, and the exceptionally rich burials at Møllegårdsmarken. On other sites, however, the situation is more ambiguous. In Sorte Muld there are traces of craft production, trade and cult activities, but there are no cemeteries containing graves with imported goods and no signs of large dwellings or halls to indicate that this was where the local elite lived.

It must be presumed, however, that this was the place where the elite established themselves, on the basis of the dense culture layers and the rich metal-detector finds. But at a site where such evidence had not been preserved, it would not have been possible to determine whether there had actually been a power-force present in the shape of a powerful individual.

As a conclusion on the questions of what it is that is central and what a centre really is, the easiest thing to do would be to follow the proposals already made and form a hierarchy, with one site as the most central, redistributing items such as imported goods to sites which were less central. However this is not the most correct approach. If one attempts to apply the theories above, it is important that they are used as an inspiration and to complement each other rather than to prove each other wrong.

If one starts by using the first theory to obtain an overview of the level on which a site is situated, on the basis of the finds, and then tries to interpret the phenomena and the functions present by using the fourth theory, finishing by fitting the evidence into a larger perspective using theory no. 5 , it should be possible to form a composite picture of a single site, based on both the overview from the first theory and the greater depth of analysis from theories 4 and 5 .

\author{
Astrid Skou Hansen \\ Afdeling for Forhistorisk Arkæologi \\ Aarhus Universitet \\ Moesgårdt
}

